\title{
Public Library Services for Immigrants in the United States: Then and Now
}

\author{
미국 공공도서관의 이민자 대상 서비스: 과거와 현재
}

Yeo-Joo Lim*

\begin{abstract}
This study examines and compares public library services for immigrants in the U.S. in the early 1900s and nowadays. U.S. public libraries in the early 1900s supported the Americanizing movement by opening English language classes and providing information that is essential for U.S. citizenship. Public librarians also recognized the importance of foreign language materials; by providing foreign language materials and developing diverse services to reach immigrants, public libraries eventually hastened assimilation processes. Despite a gap of one hundred years, the situation today is not very different. Public libraries still try hard to serve their ethnic patrons with extensive foreignlanguage collections and culturally diverse library programs, while still emphasizing English language education.
\end{abstract}

\section{초 록}

본 연구는 미국 공공도서관의 이민자 대상 서비스를 1900 년대 초와 현재로 나누어 분석 비교하였다. 1900 년대 초의 미국 공공도서관은 영어강좌를 개설하고 미국 시민으로서 갖추어야 할 정보들을 제공함으로써 미국화 운동에 앞장섰다. 공공도서관 사서들은 또한 외국어 자료의 중요성을 인식하였다. 외국어 자료의 제공과 이민자를 위한 다양한 서비스의 개발은 결국 이민자들이 미국 사회에 동화되는 것을 촉진시켰다. 100년이 흐른 지금도 상황은 크게 달라지지 않았다. 공공도서관들은 여전히 이민자들의 영어 교육에 중점을 둔 채, 포괄적인 외국어 자료 장서와 문화적으로 다양한 도서관 프로그램으로 각기 다른 나라에서 온 이민자들에게 서비스를 제공하려 노력하고 있다.

Keywords: public libraries, services for immigrants, foreign language materials, Americanization, multiculturalism, library outreach services, multicultural services 공공도서관, 이민자 대상 서비스, 외국어 자료, 다문화주의, 도서관 대외봉사, 다문화 서비스

* Doctoral Student. Graduate School of Library and Information Science, University of Illinois at Urbana-Champaign (ylim20@illinois.edu)

- Received : 5 May 2009 - Revised : 14 May 2009 - Accepted : 20 May 2009

- Journal of the Korean Society for Information Management, 26(2): 7-25, 2009.

[DOI: 10.3743/KOSIM. 2009.26.2.007] 


\section{Introduction}

According to the U.S. Census Bureau, as of March 2003, the estimated foreign-born population of the United States was 33.5 million. It is about 11.7 percent of the total U.S. population (Larsen 2004). American history indicates three streams of immigration to this day. While the immigrants of the first stream - mostly from Northern and Western Europe (1830s-1850s) - had few problems assimilating because their closeness to the earliest settlers in terms of language, religion, etc., the immigrants of the second stream of immigration - mostly from Southern and Eastern Europe (1880s-1910s) - were culturally different and had difficulties assimilating. The third stream of immigration started in the 1960s and is still going on. The immigrants of the third stream are from many different countries - mainly from Latin America and Asia - and show great cultural diversity.

Stephen Stern (1991) observes that "the library community has always responded $\cdots$ to the changing needs of ethnic groups in the United States" (p.99). The purpose of this study is to examine and compare how public libraries have reacted to the culturally different newcomers to the U.S. in the past and now. Specifically, this study sets up the past time period as 1876-1924, as the American Library Association was founded in 1876 and thus brought more systemized library services with the help of the Library Journal, which also started the same year; the Immigration Act began to be legally enforced in 1924, which brought an end to the second stream of immigration. Library services nowadays focus on the 1990s and 2000s in order to present the most current tendency. By investigating the similarities and differences between the library services in two different time periods, we can reevaluate our current services and also learn to how best to continue serving the ever-increasing foreign-born population in this multicultural nation.

\section{Immigration Histories}

The foreign-born population was 9.7 percent in 1850 . It increased to 14.4 percent in 1870 , and hit the highest percentage in 1890 with 14.8 percent of the total U.S. population (Gibson \& Jung 2006). Figure 1 shows the actual number of immigrants from 1850 to 1930 and from 1960 to 2000 . The number of immigrants increased drastically from 1890 to 1910 . Another increase began in 1980 , and it is still going on.

The first stream of immigration was in the 1830s to 1850 s, when Catholic immigrants from Germany and Ireland, and other Western Europeans and Scandinavians arrived in the United States. This is called "the first Great Wave" by historian Otis L. Graham Jr. (Jones 1999; 2004). Although there were instances of anti-foreign reactions, these immigrants had fewer problems assimilating, compared to the later immigrants. This was because they were closely related "by ties of race, of language, and of religion, to the earliest settlers," who were mainly from the same countries (Wendel 1911). 


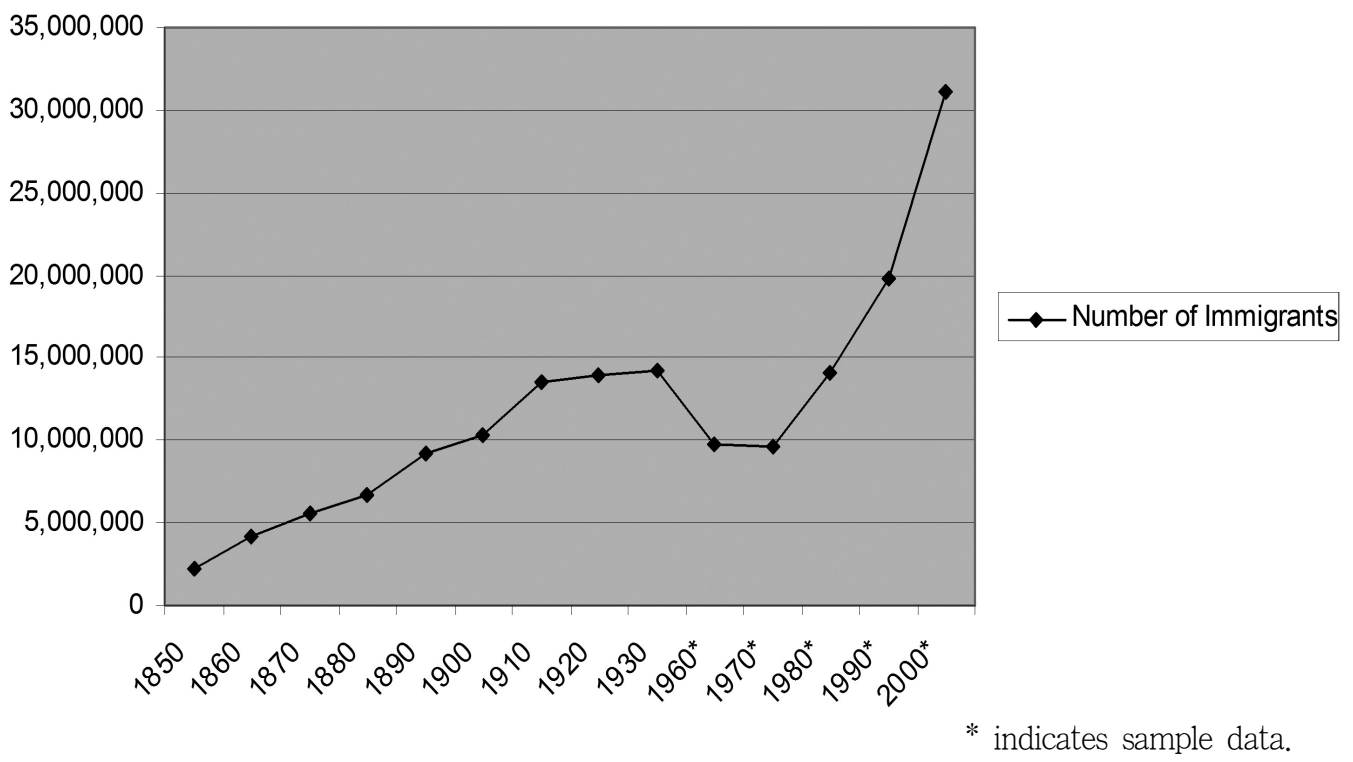

〈Figure 1〉 Foreign-Born Population in the U.S. : 1850-1930 and 1960-2000 (Gibson \& Jung 2006).

After the Civil War and economic depressions of the $1870 \mathrm{~s}$, a great number of immigrants from Europe poured into the United States. They were mostly from Southern and Eastern Europe, as well as China and Japan. The newcomers from Southern and Eastern Europe soon began to outnumber the immigrants from Northern and Western Europe. These new immigrants from Southern and Eastern Europe were culturally very different from the earlier settlers. Wendel (1911) says it was a "very decided change over the character of the immigration" (p.89). Harris (1973a) says "many Americans viewed this influx of strangers with alarm." (p.2513). Although, ironically, the "new" immigrants came to the United States for basically the same reasons as the "old" ones - freedom of religion, political upheavals, and economic crisis many conservative Americans were very critical of these new immigrants.

Asians ${ }^{1)}$ began to come to the Pacific coast from the mid 1800 s. 1849 to 1882 was the period of heaviest Chinese immigration, mostly as cheap labor contracted under a debt obligation. They lived in their own quarters (commonly known as

1) Asians at the time were not called "Asian Americans," but were called "yellow," "oriental," "the Chinese," "Chinaman," "the Japanese," etc. They were not called Asian Americans until 1965, when Yuji Ichioka coined the term in response and resistance to "Oriental" and for the purpose of creating solidarity among disparate Asian groups. 
Chinatowns) and hardly ever went out except for purposes of trade. Japanese immigrants arrived in Hawaii beginning in the 1880s. They were recruited by Hawaiian planters who sought new, cheaper labor for their plantations. These planters also recruited workers from Korea; Koreans began systematically arriving in the Hawaiian Islands in 1903, but this wave of immigration was cut short when Japan annexed the country in 1910. Many Koreans and Japanese laborers in Hawaii remigrated to the mainland and established homes in the states along the Pacific coast. By 1860 over 41,000 Chinese immigrants arrived in the United States (Lai \& Arguelles 2003). By 1910, the United States counted about 100,000 Chinese, more than 130,000 Japanese and about 8,000 Koreans.

Besides the rapidly increasing population, however, Asians were generally considered "problems" in the U.S. and that particular perspective was carried into the library field (Yust 1913). William F. Yust, who was a librarian in Rochester Public Library, in his presentation at the conference of the American Library Association in 1913, says that "It is difficult to understand how the Japanese can be a serious race problem in California where they constitute only two and one-half per cent of the population and own and lease only twelve one-hundredths of one per cent of the land. And yet it sounds as if there is trouble there." Yust himself seems to support Japanese Americans' library use by saying, "As a class of patrons they are not only inoffensive but desirable," but his remarks implies that overall attitude toward Asians in the public libraries was hostile.

The second stream of immigration was brought to an end due to the Immigration Act of 1924, also known as the National Origins Act or Johnson-Reed Act. By limiting the number of immigrants who could be admitted from any country to $2 \%$ of the number of people from that country who were already living in the United States in 1890 , it practically prohibited further immigration from Southern and Eastern Europe as well as from East Asia and India.

The national-origin quotas was abolished when the Immigration and Nationality Act Amendments of 1965 was passed in the $89^{\text {th }}$ Congress. Since the implementation of the law, there has been enormous growth of immigration from non-European nations, and the United States faces new dimensions of diversity. If the diversity of the United States in the early 1900s was mostly a variety of European origins, now the diversity includes all different cultures from all different countries around the world. America has become a so-called "multicultural" nation.

Figure 2 shows the drastic changes in distribution among foreign-born population from 1970 to 2000 . Immigrants from Latin America have increased rapidly and now comprise more than half of total foreign-born population. Following are Asian immigrants, with 26 percent of the total. The reasons for immigration vary. Some were refugees, some came to earn money, some came out of political chaos, and many others came with an "American dream," which was still valid in many countries. 


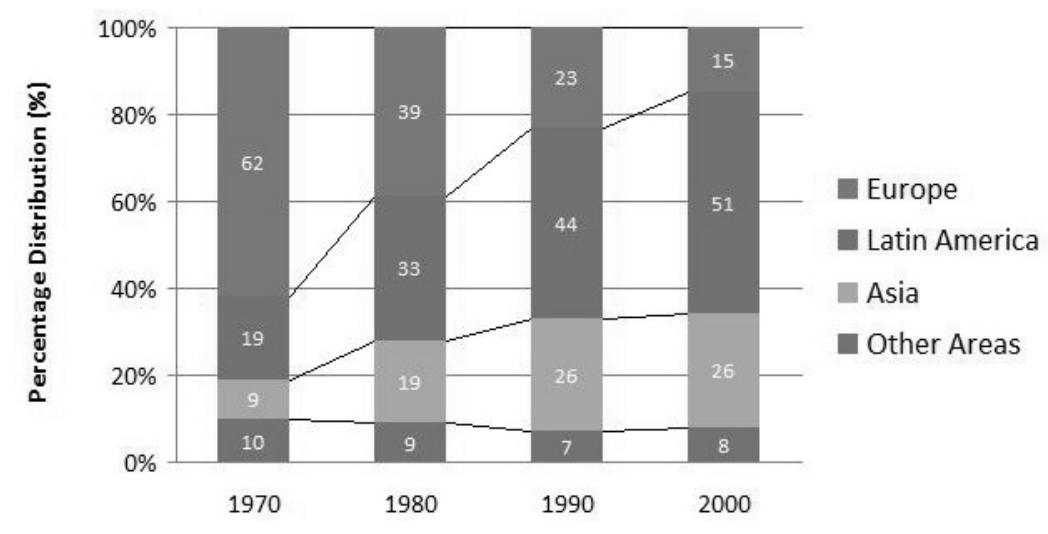

〈Figure 2〉 Foreign-Born Population by Region of Birth: 1970 to 2000, from U.S. Census Bureau (2002).

Hughes \& Seneca (1999) say that "the old model of assimilation does not work for all of the new non-European groups in our diversifying nation. New Asian and Hispanic immigrants are beset by various forms of economic and social discrimination as well. On the other hand, they are moving up economically, competing for some forms of employment and capturing space in ways very different from the black population." Despite discrimination and prejudice by the majority white society - although relatively not severe as it was in early 1900s - Asian and Latino immigrants, along with the other immigrants from diverse nations, contribute in shaping the U.S.'s "multicultural society."

\section{Americanization and Libraries}

The Oxford Companion to United State History (2001) defines the Americanization Movement as
"The effort to transform immigrants into patriotic citizens." It began with the nation's founding, but peaked in the late nineteenth and early twentieth centuries when Southern and Eastern Europeans came to the United States in greater numbers. There was no federal Americanization legislation, but several federal agencies carried out aggressive campaigns. These programs emphasized the education of health, social and civic life, and English language. John Foster Carr, the director of the Immigrant Publication Society, started publishing the "Immigrant's Guide to the United States" and several other books for educating newcomers. These books were distributed in many progressive public schools, public libraries, patriotic, religious, welfare and industrial organizations (Editorial 1920).

For librarians, Americanization meant simply a two-part process: instruction in the English language and preparation for citizenship. Plummer Alston Jones, Jr. (2004) says, "Librarians never questioned 
or debated in print whether Americanization was an appropriate mission for the American public library: it was the 'goal' of library work with immigrants.” Flora B. Roberts (1912), a librarian in a public library in Superior, Wisconsin, observed that the illiteracy rates among immigrants in the U.S. was 19.7 percent in 1899 , and 29.2 percent in 1909. As from the foundations of the nation, America aimed for public education, and it was quite obvious that one of the main goals was to educate the foreign population to read and speak in the nation's primary language.

Frank Crane (1920) gave detailed directions in teaching Americanization to librarians when he proclaimed "The Ten Points of Americanism" in Library Journal. The ten points he emphasized include American history, absence of class, democracy, the importance of education, politics, law and order, good sport, patriotism, America's attitude toward other nations, and freedom. In 1917, the American Library Association formed a Committee on Work with the Foreign Born, with John Foster Carr as the director. The Committee's responsibility was "to collect from libraries and supply them information on desirable methods of assisting in the education of the foreign born in American ideals and customs and the English language" (as cited in Stern 1991, p.81).

Librarians' active participation in the Americanizing movement was criticized by later scholars for being somewhat "repressive and autocratic" (Harris 1973b, p.34). Thus, it is quite possible that immigrants attended the Americanization pro- grams may have been instilled with all-positive aspects of America, while gradually deserting the cultural values of their origins. Although many immigrants have benefited indeed from the public libraries' Americanization programs, whether the advantage of being completely "Americanized" is as valuable as the disadvantage of loosing one's own cultural value is worth questioning.

\section{Foreign Language Materials, 1876-1924}

\subsection{Need for Foreign Language Materials}

In the midst of the Americanizing movement, some librarians began to realize the importance of maintaining the cultural values of immigrants. They insisted on having foreign language collections in the public library not only to give relief to immigrants but also to guide them to become faithful library users. While a few librarians complained that, in spite of Americanization efforts, too many immigrants still maintained their customs and traditions, others thought that immigrants had become too Americanized (Stern 1991). Librarians began to see the foreigners not just as those who need to be educated, but also as people who have hard times in this new country and therefore seek comfort and relief. Voices that supported public libraries' responsibility to provide books in the foreign languages began to resonate. As Randall 
(1931) said, "the foreign population is naturally attracted to books written in their mother-tongues" (p.79). Roberts (1912) recalls that Miss Campbell, one of the pioneers in Immigrant Services, told of a homesick looking foreigner who said to her, "I always thought until I came to your book house an American was too much hurry up to make money to take trouble for a nobody like me" [sic]. Wendel (1911) also remembers his experience with a poor woman from Venezuela. This woman, who long lay on a bed of suffering, friendless and alone in a great city, brightened up when he visited and spoke in Spanish. Wendel says the sound of her native language gave the poor woman new courage. In the same sense, library books in their native languages comforted to the new immigrants, as if the library embraced them like the mother country. In 1894, an editorial in the Library Journal posed the question of providing books in foreign languages. The editor argued that including books for immigrant populations in their native tongues in the public libraries is certainly not encouraging to good citizenship (Editorial 1894). Although not many people agreed with the editor, his argument represents the popular thinking of the time (Jones 1999). Askel G. S. Josephson (1894), in his reply to the editorial, said, "If the public library will have any influence upon the foreign-born Americans, they ought to make some effort to draw them under this influence. This is best made in providing them with books in their own languages, and about their own country" (p.364).

\subsection{Acquisition and Circulation of Foreign Language Materials}

Foreign language materials were greatly welcomed by many immigrants once they were included in the public library collection. Librarians had various routes to find appropriate books for their immigrant patrons. Foreign language materials were either directly imported from Europe or acquired through vendors and dealers. These vendors and dealers usually had their major centers in New York. Sometimes acquisitions librarians went abroad to purchase foreign materials. Their buying trips were not just for their own respective libraries, but also for other libraries that collect the same language materials. Becoming familiar with and knowing more about the culture their patrons came from was another reason for these trips (Jones 1999). Collecting foreign language materials was not an easy task for a librarian who did not know the languages. Thus, some librarians who were able to deal with the collections themselves made lists of appropriate titles, sometimes with the help of foreign-born library users, and distributed them through various methods: mail correspondence, journal articles, bibliographies, etc. The ALA Publishing Board also published the Foreign Book List series from 1907 to 1916; these seven guides helped with the selection and acquisition of books in German, Hungarian, French, Danish and Norwegian, Swedish, Polish, and Russian (Jones 1999). These books and periodicals were quite different from the "Americanization 
Collections," which consisted of "civics manuals, histories of the new country in easy English, and biographies of the foreign-born whom America now proudly claims as her own" (Learned 1924, p.43). American and British literature translated into foreign languages, or foreign literature translated into English, were also collected.

The circulation of foreign language materials was phenomenal. According to national research about the circulation of foreign books at the Chicago Public Library by Randall (1931), foreign language books were circulated an average of 6.24 times each per year, which is similar number to that of regular English books - 6.84 times each per year. At the New York Public Library, the circulation of foreign language books was even higher than that of regular English books; foreign language books were circulated 4.24 times per year, while regular English books were circulated 3.71 times per year. Librarians often found that foreign language newspapers attracted immediate interest among immigrants (Fain 1983). Randall's research shows that generally, the greater the ratio of the number of books per person, the more on the average each person reads. However, there was no discernible correlation between the number of books per capita and the circulation per book, in the specific case of foreign collections. Also, the size of the foreign collections had no discernible impact to the circulation per volume. Two possibilities are hypothesized: some nationalities read more than others, or the books in certain libraries are better chosen than those in others. The latter seems more plausible. This research result implies that just collecting foreign language materials does not solve all the problems. The more important task is to find the right person who is most informed about the foreign literature and can make the right decisions in collection development.

\subsection{Opposing Views against Foreign Language Collections}

Although many big libraries actively collected and provided foreign language materials for the new immigrants, many other libraries did not participate in this movement. It was partly because of the lack of budget or appropriate personnel, and partly because of the library's policy. According to Randall (1931), one librarian confessed, "It has been our policy $\cdots$ not to buy foreign literature in the original language, but to buy everything we could learn of in a foreign language that was a translation of American literature $\cdots$ etc.” (p.83). Randall indicates that this was a library in a city which had a foreign born population of 32.3 percent $^{2}$ ). The uncooperative attitude towards foreign language collections, unfortunately, still exists among some current public librarians. There are, however, also many advocates, including the American Library Association, who promote the needs of foreign language materials in the library, which opens up the eyes of the narrow-minded librarians.

In the beginning of foreign language materials

2) Randall does not mention more specific information about this city - i.e., name or location. 
services, some people expressed concern that these materials would prevent immigrants from learning English, and thus delay assimilation. However, experience has shown that, despite some cases that retarded the achievement of English, it has hastened assimilation in most cases (Roberts, 1912, p.167). Taken as a whole, by providing foreign language materials in the public library, America could supply a warm atmosphere to the new immigrants, which encouraged them to feel secure and attached to the nation.

\section{Foreign Language Services, 1876-1924}

\subsection{Foreign Language Assistants}

Foreign language assistants were needed greatly in order to make immigrant patrons more comfortable in the public library, and to facilitate the publication of printed finding aids and bibliographies for foreign language materials. Josepha Kudlicka, a Polish assistant in William Ives branch library in Buffalo, N.Y., not only grew the Polish collection in her library, but also put out the voice of Polish immigrants by writing in the library journals. In the article in Public Libraries, Kudlicka (1910) asserts that librarians should not "Americanize" the foreigners too soon. She says, "You cannot make a good American out of a poor Pole. If we love our country we will love yours all the more. Let us keep the best that is in us, the love for our traditions and language, our deep religious and patriotic sentiments, and you will have better and nobler citizens" (p.376; emphasis by the author). Some large public libraries in the cities could luckily employ foreign language assistants, but when it was impossible, librarians tried other ways. J. Maud Campbell, a public librarian in Passaic, New Jersey, suggested asking the immigrant patrons themselves. Campbell said that "They ([immigrants]) take pride in showing you what good books there really are in their literature" (as cited in Aderman 1983, p.262). Campbell's case seems to point out the essentials of library service for immigrant patrons; interest in the ethnic culture and recognition of each individual immigrant as a valuable member of the community. These are also the basic steps to embrace newcomers of different origins naturally and gradually, and further support them to be noble citizens of the U.S.

\subsection{Community Outreach}

Outreach to ethnic communities was one way of supporting recent immigrants' adjustment to this new country. The public library made the existence of library services known to the ethnic groups, and gained information about the ethnic community in order to develop better services for them. Librarians surveyed their communities to find out details about the population, ethnic and national representation, religious affiliations, labor unions, fraternal and social organizations, and businesses. The information they gained from the survey was 
not just for knowing more about the community, but also for providing appropriate reference and referral services for their immigrant patrons (Jones 1999). Wendel (1911) suggested librarians to collaborate with the community heads. He especially emphasized getting help from the religious leaders. This is remarkable, as it is still one of the most useful ways to approach ethnic populations. Public library services for the immigrant populations were often advertised in the local foreign language newspapers, which proved to be the most successful method of publicizing (Jones, 1999, p.20).

\subsection{Immigrant Children as Mediators 3 )}

Many immigrant children served as essential mediators between their parents and the public library, because they had more chances to visit the library and because they usually had better English skills than their parents had. The American law mandated that children must attend school, which led to immigrant children's frequent uses of public libraries. Public libraries supported schools in various ways, including homework assistance and forming "school departments" in the public libraries (Fitzgibbons 2000; Jenkins 2000). Many immigrant children visited public libraries to get homework support from the librarians, and naturally became regular library users. These children played the role of mediators between their parents and the library by bringing their parents to the library, or borrowing books that their parents wanted to read. Kudlicka (1910) says that her library was able to encourage parents to use the library, even those who did not write or read came, while the children read to them. Also, Roberts (1912) describes a conversation between a child and a librarian, which is a good example of immigrant parents' reliance on their children in terms of library use:

"My mother she wants a book," says a small urchin.

"What kind of a book?" asks the librarian.

"One about princes and princesses, and with weeping in it."

Eventually, the librarian sent a book that matched the order of the children, which originally came from the mother. According to Sung (1987), parents and children "are at the same starting line" right after immigration, but soon the children's English skills surpass their parents' English skills because of school education. As a consequence, parents tend to depend more and more on their fluent-English-speaking children, especially in terms of services that are provided only in the "dominant language and mainstream institutions," which includes the public library services (Chu 1999). Immigrant parents' dependence on their children

3) ICM (Immigrant Children Mediators) is a term first coined by Clara M. Chu in her conference proceeding "Immigrant Children Mediators (ICM): Bridging the Literacy Gap in Immigrant Communities" (Chu 1999). 
further brings about the collapse of traditional positions in the family, which will be discussed later in this paper.

\subsection{Adult Immigrant Services and the Evening Schools}

It is quite true that library services for adult immigrants were somewhat neglected compared to services for immigrant children, as public libraries tended to concentrate on collaboration with the public schools (Jones 1999). However, that does not necessarily mean that adult immigrants were ignored. Many libraries report night classes for foreigners (Roberts 1912). Evening schools were actually the "great Americanization agency for immigrant adults" (Jones 1999, p.18). Immigrants, the prospective citizens, were taught the language of their new country, its law, customs, and ideals. In some libraries, lectures were also given in the immigrants' native languages. Library clubs of the different nationalities were encouraged to hold their meetings at the library as well. As mentioned earlier, the Americanization programs were usually oneway, didactic, and demanded the complete transformation of an ethnic individual to "the great American" citizen. A question arises whether the adult immigrants who attended evening schools viewed the public library as a place where they could read books and spend good times with their family, as well as a social institution for administrative help.

\subsection{Concern for Maintaining Each Ethnic Group's Culture}

An editorial in New York Libraries said an interesting statement that could have alarmed many librarians who were absorbed in Americanization movement. It read: "Under the powerful assimilating influences of American life to-day, the danger is not that the foreign languages will be retained too long - the danger is that in a generation or two they will be lost as an element of power and culture, and that the rich inheritance of racial traditions and characteristics which give America a peculiar interest and distinction, will disappear" (as cited in Roberts 1912, p.167). This remark is very interesting because it is still an on-going and never agreed issue; whether America should be a "melting pot" or a "mosaic or cultural tapestry" (Berry 1999). The latter is more welcome these days because it speaks to the individuality of all cultures and backgrounds, but there are still many who support the "melting pot" metaphor.

Breaking of the family ties was another major issue. In an average immigrant family in an average American city, usually the father went out to work and joined other immigrant colleagues who share the same native language, while the mother stayed home, and the children went to school, because they were compelled by law. The children's English skills quickly increased, and the better the children's English get, the more the parents tended to rely on their children, when dealing with problems which need English language skills. Gradually 
the traditional positions in the family collapsed and parents lost their authority. It was very possible that someday the child shouted at his mother, "Shut up talking about Bohemia; we are living in America now" (Roberts 1912). Again, this still remains a serious issue in every first generation immigrant family.

\section{Library Services for Immigrants, Now}

\subsection{Similar Services Still Continue}

More than one hundred years later, although the composition of immigrants has changed, the issues around public library services to the immigrants are amazingly similar to those expressed in the early 1900s. There are still debates whether public libraries should provide materials in the native languages of the immigrants, while many libraries open ESL (English as a Second Language) programs and invite their immigrant patrons. Libraries try to hire foreign language assistants or ethnic librarians with MLIS degrees, and actively collect foreign language books, periodicals, and DVDs. On the other hand, still quite a large number of libraries complain that they do not know how to reach their ethnic populations, or even do not recognize the needs of the small voices of minority library users.

\subsubsection{The Need for More Diverse Language Collections}

After the abolition of the national origins quotas, large streams of immigration flowed into the United States. A lot of different ethnic people from all different countries came to America, and the U.S. practically became a "multicultural" society. According to the U.S. Census Bureau, foreign-born people are mostly concentrated in the metropolitan areas. In 2000, Los Angeles, New York, San Francisco, Miami, and Chicago had half of the nation's foreign-born population (Larsen 2004). Naturally, libraries in these areas are more active in collecting and providing foreign language materials. Queens Borough Public Library in New York, which serves a population of 2 million in one of the most ethnically diverse counties in the U.S., circulates materials in 65 languages to serve its patrons who come from 90 different countries and speak 120 different languages; it has the largest collections in the U.S. for general readers in Spanish and Chinese, as well as extensive collections in Korean, Russian, and South Asian languages (QBPL 2009; Strong 2000). New York Public Library's Donnell Library Center actively collects in 55 to 60 languages (Rogers 2003). Creating collections for these multicultural populations is becoming more complex and challengeable. Staff members who can speak foreign languages are needed more than ever.

6.1.2 The Need for More Cultural Sensitivity As more cultures came in, librarians needed to 
be more cautious about the cultures of the community they serve. As mentioned earlier, a public library is not just a place that has books in it. For new immigrants, it can be a place to confirm that they are welcomed in this country, or to recognize that they are still aliens in this strange land. Hall \& Grady (2006) say that if a librarian neglects a Spanish speaking child's reference question by saying "No Espanol," just because the Hispanic staff was not there at that moment, it will have a negative impact on the child's family and their perception of the library. Lia Londono, a librarian in a Chicago college, asserted that librarians should recognize the differences among the many groups who are labeled as "Hispanic," such as Latinos, Mexicans and Chicanos. She pointed out that these labels have different sociopolitical implications and that these groups come from geographically different countries and have different social norms and cultures. Thus, it is very important that librarians familiarize themselves with these facts before they attempt to create services and programs for these communities (as cited in Pokorny 2003).

In some cultures, library access was restricted to the public for a long time. In some other cultures, general library use behavior is quite different from that in the U.S. For example, "the new Asian communities are simply not aware of the reference services offered by public libraries and the vast amount of information that could be culled from these collections" (Zhang 2001, p.143). Because these people do not know the availability of reference services, they seldom go to the public library to ask what they want. Then, the librarians do not know their needs, so they just assume that present library services are sufficient and do not go farther. In order to prevent this vicious cycle, public libraries should be more sensitive about each ethnic group's culture and characteristics, and provide appropriate outreach services for them.

\subsubsection{Immigrant Children as Mediators}

Immigrant children are still serving as mediators for their non-native minority parents to get information that is provided primarily in English. According to Chu (1999), however, most children do not cite the library as an information source. The most cited sources by them were individuals, the phonebook, and the media. This means that however well librarians prepare reference services for the immigrants who do not speak English, it is almost impossible to actually get resources to them, and vice versa. Thus, in addition to providing services for the immigrant children and expecting them to be bridges between the library and the parents, public libraries should develop better ways to approach the immigrant adults as well.

\subsection{New Attempts}

Although the basic approach to serving immigrants has not changed much since the early $1900 \mathrm{~s}$, in recent times public libraries introduced more active outreach services to their immigrant patrons. Public libraries these days not only build foreign language collections, they also provide reference 
services in diverse languages online and offline, create library catalogues that can be searched in diverse languages, and physically reach out to ethnic communities who do not have access to traditional library services. The attempts to produce and recruit ethnic minority librarians also reflect the public libraries' efforts to serve the ever-growing population of ethnic immigrants.

\subsubsection{WorldLinQ}

The Queens Borough Public Library in New York has continued its long history as a leader in developing specialized services that meet identified community needs. In 1996, WorldLinQ, a new service of selected international internet sites, was made available for customers who speak languages other than English, which was developed through a grant from AT\&T (www.worldlinq.org). From the beginning of WorldLinQ Project, the library fielded language-specific teams of professional librarians, known as the WorldLinQ Team, who were bi- or multilingual, familiar with internet-search techniques, and interested in using a Web page editor. "It was challenging to identify staff who were capable of doing this kind of work, even in place as diverse as Queens," says Gary E. Strong (2000), the director of the Queens Borough Public Library in Jamaica, New York. Currently, WorldLinQ provides multiethnic web information in nine different languages - Arabic, Bengali, Chinese, Croatian, Czech, French, Greek, Hebrew, Italian, Korean, Polish, Romanian, Russian, Spanish, and Ukrainian. InfoLinQ, the Queens Library's OPAC system, can be searched by five different languages (Chinese, French, Korean, Russian and Spanish) other than English. OCLC's CJK software supports efficient cataloging of Chinese, Japanese, and Korean materials with CJK characters, so that library users can search and access local library records displaying both the Romanization and Asian language characters.

\subsubsection{InfoBUS}

InfoBUS is a mobile branch library dedicated to serving the immigrant and refugee population in Memphis-Shelby County in Tennessee. There are eight wireless notebook computers for patrons in the InfoBUS, as well as ESL (English as a Second Language) collections and foreign language collections. Staff includes three bilingual librarians and a full-time driver/circulation clerk (Virgilio 2004). According to King \& Skanks, Chat rooms and portal sites on Vietnamese culture, ESL web pages, and Latino newspaper are the most popular services in InfoBUS (as cited in Pokorny 2003). InfoBUS is a good example of recent public library outreach service. It shows that librarians no longer just sit on their chair and wait for the patrons come. What is more meaningful is that it reaches to the population "who may not have access to more traditional venues" (Pokorny 2003).

\subsubsection{Innovative Online Services}

Recently, librarians have been developing innovative online services designed to meet the needs of $21^{\text {st }}$-century patrons. Real-time virtual reference, 
or multilingual chat reference, is at the forefront of these services (Cichanowicz \& Chen 2004; Lupien 2004). Indeed, a lot of library resources have migrated to the on-line environment, and it is no wonder that Lupien says, "Offering service in a second language is useless if the library's collection has no online resources in that language to offer patrons" (p.54). According to many librarians who offer virtual reference, however, staffing seems to be the most complex issue to deal with (Lupien 2004). This is quite true, because virtual reference librarians should not only read and understand the language, but also have to type quickly and accurately in that language. As more library services are placed online, more librarians with ethnic background will be needed.

\subsubsection{Librarians Heading for Diversity}

It is very hard to find any comments about an ethnic minority librarian in the early 1900s' library journals in the United States. Although there is no explicit statistics about the ethnic identities of public librarians in the early 1900s, it is generally assumed that most of them were white women from the middle class. About one hundred years later, we can occasionally find ethnic librarians in the public libraries. However, they are still very few. According to Saye \& Wisser (2003), only $11.3 \%$ represent students of color including the four main ethnic minority groups (African Americans, Asian Americans, Hispanic Americans, and Native Americans) in ALA-accredited LIS schools. Considering that ethnic minorities consisted of
$31.3 \%$ of total U.S. population in 2003 , this is astonishingly small amount. Josey (as cite in Kim \& Sin 2006) says, "Unless the LIS schools and the library and other professional association develop a comprehensive plan to support a massive recruiting program, the gap between LIS and US population may widen even further; and the librarian population will not reflect the users in the communities that they serve."

\section{Conclusion}

Despite a gap of one hundred years and the difference in the composition of people entering U.S., public library services for immigrants in early 1900s and nowadays are not very different each other. In early 1900s, librarians were at the forefront of Americanizing movement. With a mission to assimilate the immigrants into U.S. society, public libraries opened evening schools and taught them English, democracy, law and order, politics, and other information, which were considered to be essential for U.S. citizens. Today's public libraries also try hard to support immigrants, but not in the autocratic and narrow-minded way as the earlier librarians did one hundred years ago. ALA President Loriene Roy indicates that U.S. public libraries should assist the "linguistically isolated" so that they could use the library as a place for "education, self-help, and lifelong learning" (ALA 2008a, p.12). In other words, today's public library services for immigrants focus more on helping the 
newcomers adjust and enjoy library services, rather than making them into "the great American citizens."

Some librarians in the early 1900 s did recognize the need for foreign language materials and the importance of maintaining cultures and traditions of ethnic groups. They provided foreign language books and periodicals, hired foreign language assistants, and reached out to the ethnic community. Public libraries nowadays still maintain similar services, only they are more active and more technological. A recent nation-wide study about U.S. public library services to non-English speakers reveals that foreign language collections are the most frequently used services by the immigrant patrons, followed by in-library ESL (English as a Second Language) classes (ALA 2008b). This research result indicates that immigrants' need for reading materials of their own language is still great. One thing to consider is that today's immigrants are different from the earlier immigrants of one hundred years ago. While most of the immigrants in the early 1900s were from Europe, today's immigrants come from many different nations especially from Latin America and Asia: they not only suffer from economic difficulty or harsh living conditions, but they also often face racial discrimination. Therefore, public libraries' foreign language collections may be more than helpful in embracing this isolated population and giving them comfort and relief. The collection may also attract immigrants who do not have prior experiences of public library services from their countries of origin, and further encourage them to become faithful library users. However, there are still voices opposing to providing foreign language materials in the public library, even in the library field. Cultural insensitivity of a librarian is often issued, and the student population in LIS schools is far less diverse than the U.S. population.

Hall \& Grady (2006) throw an important issue which the public librarians should seriously consider. They say, "The reality is that an ever-changing, ever-expanding user base means ever-changing, ever-expanding expectations from services and service providers" (p.42). Now, America is commonly acknowledged as a multicultural society. Oxford English Dictionary (2009) defines "multicultural" as "of or relating to a society consisting of a number of cultural groups, esp. in which the distinctive cultural identity of each group is maintained." Therefore, in order to keep up with the changed needs and expectations of multicultural patrons, public libraries should make efforts to provide diverse services that could support maintaining each ethnic group's culture and tradition. 


\section{References}

ALA. 2008a. "ALA Unveils Study on Library Service to New Americans." American Libraries, 39(5): 12.

ALA. 2008b. "Serving Non-English Speakers in U.S. Public Libraries: 2007 Analysis of Library Demographics, Services and Programs." Retrieved June 1, 2009, from. $<$ http://www.ala.org/ala/aboutala/offices/ol os/nonenglishspeakers/index.cfm>.

Americanization. 2001. In the Oxford Companion to United State History. NY: Oxford University Press.

Berry, J. N. 1999. "Culturally Competent Service.” Library Journal, 124(14): 112.

Chu, Clara M. 1999. "Immigrant Children Mediators (ICM): Bridging the Literacy Gap in Immigrant Communities." Conference Proceeding of the $65^{\text {th }}$ Annual Conference of the International Federation of Library Association, Bangkok, Thailand, August 20-28.

Cichanowicz, E. M. and Chen, N. 2004. "Planning for Multilingual Chat Reference Service in a Suburban Public Library System.” The Reference Librarian, 85: 115-126.

Crane, Frank. 1920. “The Ten Points of Americanism.” The Library Journal, 45: 214-215.

Editorial. 1920. "The Immigrant Publication Society." The Library Journal, 45: 213-214.

Editorial. 1894. The Library Journal, 19: 328.

Fain, E. 1983. "Books for New Citizens: Public
Libraries and Americanization Programs, 1900-1925.” in R. M. Aderman (Ed.), The Quest for Social Justice (pp.255-276). Madison, Wisconsin. The University of Wisconsin Press.

Fitzgibbons, S. A. 2000. "School and Public Library Relationships: Essential Ingredients in Implementing Educational Reforms and Improving Student Learning." School Library Media Research, 3.

Gibson, Campbell and Jung, Kay. 2006. "Historical Census Statistics on the Foreign-Born Population of the United States: 18502000." Population Division Working Paper No. 81. U.S. Census Bureau, Washington, D. C.

Hall, T. D. and Grady J. 2006. "Diversity, Recruitment, and Retention: Going from Lip Service to Foot Patrol." Public Libraries, 45(1): $39-46$.

Harris, M. 1973a. "The Purpose of the American Public Library: A Revisionist Interpretation of History.” Library Journal, 98: 2512-2513.

Harris, M. 1973b. "The Purpose of the American Public Library in Historical Perspective: A Revisionist Interpretation.” ERIC Clearinghouse on Library and Information Sciences, Washington, D.C.

Hughes, J. W. and Seneca, J. J. 1999. America's Demographic Tapestry: Baseline for the New 
Millennium. New Jersey, Rutgers University Press.

Jenkins, Christine A. 2000. "The History of Youth Services Librarianship: A Review of the Research Literature." Libraries \& Culture, 35(1): 103-140.

Jones, Plummer A. 1999. Libraries, Immigrants, and the American Experience. Westport, Connecticut: Greenwood Press.

Jones, Plummer A. 2004. Still Struggling for Equality. Westport, Connecticut: Libraries Unlimited.

Josephson, Askel G. S. 1894. "Foreign Books in American Libraries.” The Library Journal, 19: 364 .

Kim, K-S. and Sin, S-C. J. 2006. "Recruiting and Retaining Students of Color in LIS Programs: Perspective." Journal of Education for Library and Information Science, 47(2): 81-95.

Kudlicka, Josepha. 1910. "Library Work among Foreigners." Public Libraries, 15: 375-376.

Lai, E. and Arguelles, D. (Eds.). 2003. The New Face of Asian Pacific America: Numbers, Diversity \& Change in the 21st Century. San Francisco: AsianWeek, with UCLA Asian American Studies Center Press.

Larsen, Luke J. 2004. "The Foreign-Born Population in the United States: 2003." Current Population Reports, P20-551. U.S. Census Bureau, Washington, D. C.

Learned W. S. 1924. The American Public Library and the Diffusion of Knowledge. New York,
Harcourt: Brace and Company.

Lupien, P. 2004. "Bilingual Virtual Reference." Computers in Libraries, 24(5): 6-8, 53-54, 56. Pokorny, R. E. 2003. "Library Services to Immigrants and Non-Native Speakers of English: From Our Past to Our Present.” Bookmobile and Outreach Services, 6(2): 21-34.

QBPL (Queens Borough Public Library). 2009. “Queens Library Facts.” Retrieved May 1, 2009, from. $<$ http://www.queenslibrary.org/UserFiles/ File/MCD/35240508_singlepages.pdf $>$.

Randall, W. M. 1931. "What can the Foreigner Find to Read in the Public Library?" Library Quarterly, 1: 79-88.

Roberts, Flora B. 1912. "The Library and the Foreign Citizen." Public Libraries, 17: 166-169.

Rogers, M. 2003. "Serving up World Languages." Library Journal, 128(11): 42-44.

Saye, J. D. \& Wisser, K. M. 2003. “ALISE: Library and Information Science Education Statistical Report 2003 - Students.” Retrieved May 1, 2009, from. $<$ http://ils.unc.edu/ALISE/2003/Students/St udents01.htm>.

Stern, Stephen. 1991. "Ethnic Libraries and Librarianship in the United States: Models and Prospects." Advances in Librarianship, 15: 77-102.

Strong, Gary E. 2000. "LinQing the World to Queens - and Queens to the World." American Libraries, 31(9): 44-46.

Sung, Betty Lee. 1987. "The Adjustment Experience 
of Chinese Immigrant Children in New York

City." New York: Center for Migration Studies.

U.S. Census Bureau. 2002. "Coming to America: A Profile of the Nation's Foreign Born (2000 Update)." U.S. Department of Commerce, Washington, D. C.

Virgilio, D. 2004. "InfoBUS: Serving Immigrant and Refugee Populations.” In R. Osborne (Ed.), From Outreach To Equity (pp.9-11). Chicago. American Library Association.

Wendel, F. C. H. 1911. "The Stranger Within Our
Gates: What Can the Library Do for Him?" Public Libraries, 19(3): 89-92.

Yust, William F. 1913. "What of the Black and Yellow Races?" Proceedings from the Conference of the American Library Association. Katerskill, N.Y.

Zhang, X. 2001. "The Practice and Politics of Public Library Services to Asian Immigrants.” In (ed. Luevano-Molina, S.) Immigrant Politics and the Public Library. Westport, CT: Greenwood Press. 